\title{
Impact of Macro Economic Variables on Return on Assets of Textile Industry of Pakistan
}

\author{
Irfan Ullah, Humaira Noreen, Zia Ur Rehman, and Naveed Shinwari
}

\begin{abstract}
The aim of this study was to find the impact of Inflation rate, Interest rate, Foreign direct investment, Trade openness and Exchange rate on Return of assets of textile weaving sector of Pakistan during the period of 1997 to 2019. The Dependent variable was Return on Assets while Inflation rate, Interest rate, Foreign direct investment, Trade openness and Exchange rate were independent variables, Data for the study was obtained from secondary sources like World Development Indicator, Pakistan Stock exchange and financial stability review issued by State Bank of Pakistan during 1997 to 2019. ROA were collected from Annual reports of the selected textile businesses (weaving sector). The results of Co-integration indicated the long run relationship among the variables. However, inflation rate, interest rate and exchange rate have positive and significant impact on return on Assets of textile weaving sector of Pakistan, on the other hand Foreign direct investment and Trade openness have insignificant effect on Return on assets of textile weaving sector of Pakistan. This paper is limited to linear framework some results may be sensitive to non-linearities, a non-linear frame work should be included in future research.
\end{abstract}

Index Terms - Return on Assets, Inflation Rate, Interest Rate, Foreign direct investment, Trade openness and Exchange Rate.

\section{INTRODUCTION}

A country can be economically or financially sound by means of its natural resources as well as industries working in it. Besides other industries, the primary concern of textile industry is production design and distribution of cloth yarn and clothing [40]. The textile sector enjoys a pivotal position in the exports of Pakistan as sources indicate that Pakistan has eighth number in largest exporting countries of Asia in textile, contributing $8.5 \%$ to the total GDP [7]. The annual textile trade of the world is 18 trillion US \$ and grows at $2.5 \%$ annual rate. The annual volume of total world textile trade is US\$ 18 trillion which is growing at 2.5 percent annually however, Pakistan's contribution to world textile trade is less than one percent. The manufacturing sector development is having highest priority since independence and main focus persisted on Agro-based Industries. As in textile sector particularly Pakistan remains one of the prominent producers of cotton in the world, by using its complete abundant resource of cotton. Statistics also shows that at present, there are 1,221 ginning units, 442 spinning units, 124 large spinning units and 425 small units which produce textile products [41].
Survey reveals that Pakistan has fourth number in largest cotton producer's worldwide and third largest consumer of the country's agricultural output, which enriches the level of employment and trade surplus [7]. Textile industry is also one of the main industries that contributes to the foreign exchange by promoting export to the different countries [17], hence textile sector considered as a backbone of the Pakistan's economy. Despite many handicaps associated with the textile industry of Pakistan, Cotton sector is short of modern equipment also Research \& Development and finance bill is also main burden of the industry, there are many factors like fertile land, efficient labor, conducive weather conditions, agricultural resources etc. still favors the textile industry of Pakistan [6].

Textile sector because of its potential attracts local and foreign investors to invest in. By means of foreign direct investment investor outside the country contributes in the sector and get profit in return i.e. Return on investment, (ROI), earning per shares (EPS). Arguing about FDI, it's an investment made by one country in another country which reflects as a catalyst for economic growth. Subsequently, studies for instance [8] and [37] highlighted the importance of FDI and trade economic growth.

On one side if increase in FDI and trade as positive impact on economic growth there are some other factors which have adverse effect on economic growth i.e., inflation, interest rate etc. linking inflation and interest rate with textile sector [16] declared inflation and interest rate has an adverse effect on textile's production resulting downsizing in textile sector and ultimately caused decline in export efficiency. In the context of Pakistan in year 2008, Pakistan has faced high double-digit inflation i.e 25.23 and interest rate 14.05 due to lack of investment and output growth. [36]. Therefore, one can say that high interest rate is an indicator of continues inflation in the textile sector. Hence inflation and interest rate are directly proportional to each other.

Trade openness or trade liberalization is considered to be a tool that enhances the industrial productivity by reducing tariff barriers and accrued global economy but this impact of trade openness is contextual and has been varied from country to country [26]. Generally, an economy comprises of three sectors that are. export, import and non-tradable sectors. The prices of these tradable goods are used for the purpose of export and import which are determined by means of world prices at the ratio of country's exchange rate [33]. 


\section{Problem Statement}

Pakistan is populated country having high demand for textile products, consumes the largest quantity of cotton. The reason of its productivity growth is due to resource of labor endowment, agricultural land and best suited climatic conditions, it is highly desired to chalk down the best strategy against its downfall either which of the variables would have more impact on its performance for the best compete in the world. According to [5] stated that last four decades' textile industry of Pakistan showed notable growth in the past but in the last decade it has been noticed that rise in inflation has shrunk the profitability. The shutter down of textile mills in Faisalabad has shifted its demand to the other South Asian Countries like India, China, and Bangladesh. Therefore, this study seeks to determine the impact of FDI, Interest rate, inflation rate and trade openness on the return on assets of textile weaving sector in Pakistan for the period of (19972019).

$\boldsymbol{R Q}$ : Is there any impact of macroeconomic variables on return on assets?

\section{LITERATURE REVIEW}

Many researchers have been seen regarding measurement of performance of industry. Similarly, [24] stated that performance measurement refers to the procedure of evaluating actions competence and its recital while [9] described "Performance management as a process where an industry administers its recital with functional strategies and objectives" which elaborates the significance of the outcome of an industry. It can predict that the financial sectors of developing countries are drown in the flood of foreign capitals against the global standards which are poor in capital [28]. Hence such like case of Pakistan which is capital intensive country, the performance of a firm or an industry also depends upon macroeconomic variables. Globalization of economy is referred as increasing interdependence pf world economies as a result of growing scale of cross-border trade of commodities and services, flow of international capital and wide and rapid speed of technologies [29].

Foreign Direct Investment has positive but insignificant impact on export performance. As stated in a study by [20] predicted a positive association of FDI on domestic firm's production and export performance, hence FDI creates industrial technological advancement for domestic economy and discover bulky suppliers. As per study of [30] the cumulative system model in which countries specialize in several final goods and services, the competence and factual performance can be changed by backward linkages but have not more impact on industrial progress.

As per study of [21] in developing countries out ward FDI's main source is FDI inflows. Hence by subsidizing FDI inflows towards export-based investment and service sector economic growth can be accelerated which will have better effect on balance of payments. The following factors are used to find out the attractiveness of a country for FDI; Stable exchange rate, high degree openness (Number of restrictions on imports \& exports) low inflation (reduction of economic uncertainty and risks) skilled labour, protecting measures of host country, low cost energy and natural resources and geopolitical advantages. Therefore, FDI has a significant role in economic development Inverse to the above factors FDI can be affected negatively by the following factors: intervention in national issues, technological dependency, cultural changes, reduction of tax revenues, exclusion of national capital, environmental pollution and balance of payments.

According to [10] considered trade liberalization has a major role in all economic activities; contend that economic growth positively impacts the social progress. Third, high economic growth can tackle the problem of poverty and unemployment which may achieve if domestic economy can assimilate with liberty worldwide. Last, every country cannot produce everything it needs, hence would depend on other country to meet its domestic demand.

Therefore, trade openness expands business opportunities for local as well as foreign businesses [25] Hence the study focusses textile sector of Pakistan specifically because of land labour endowment and best suited climate led to produce more for local and trade purposes which also enable this country to diminish the above cited problems and would lead to best compete worldwide.

In line with previous research, [38] raised the question of how economic growth becomes beneficial due to trade liberalization and stated while go through the benefits of trade openness, may take notice of imperfections of markets and economies of scale which gave rise the hypothesis that growth can be achieved by trade restrictions. [18] stated that Pakistan's textile could not get benefit of quota elimination so far, a liberal trade environment become synonymous with free trade when there reduced or eliminate trade interventions through government.

As accord to the study of [34] the impact of high tariff on textiles and clothing sector and found the tariff limit of 12 to $30 \%$ in US, European Union and Canada also described the association between trade openness and export performance of the said sector and assessed the effect of trade openness on production efficiency of Pakistan's Textile sector by reduction of trade barrier and found negative impact of trade barriers include tariff peaks, tariff quota on its performance, which shows that trade liberalization has an impact on the said industry. Trade openness have significantly contributed to economic growth in Asian both developing and developed countries while passing through a more liberal regime during the past few decades [35]. Above discussion shows that both researchers and policymakers realized the benefits of trade towards industrial performance and economic growth through various channels.

As stated by [32] Trade liberalization is often found as important factor toward economic growth in the literature, both empirically and theoretically the relationship between trade openness and economic growth is more unclear and debatable. Theoretically, it proposes in favor of trade liberalization rests on arguments of greater economic efficiency enhanced by lower costs of trade, lower transaction costs, increased specialization, scale economies, and competitive pressure, which in turn fosters better economic performance and increases in economic growth rates, Hence, if examine the cointegration between economic growth and trade liberalization, it is essential to know the degree discrimination of industrial and technological sophistication 
between trading partners as well as the importance of scale economies and policy stances.

According to study of [11] the essential goals in economic performance to attain macroeconomic goals are monetary policy, fiscal policy, international economic policy and income \& price policy. [13] stated that for the development of economy monetary policy should be considered primarily. The Bank Negara Malaysia (BNM) has frequently adopted annual inflation of 2.5-3.5. As the results of this study shows that inflation influenced the economic growth strongly, means that inflation should be controlled constantly.

As stated by [4] that association of economic growth and monetary policy in developing economy with primary focus on Malaysia. Mainly the study will focus on measuring economic growth in relation with interest rates, inflation, money supply and performance of the economy. Generally, many of policies effectiveness, transmission and implications differ in advanced countries and developing countries, which face the weak institution and financial under development. Similarly, the industrial effect of Chinese import penetration has a positive effect on textile sector of Zimbabwean manufacturing sector and the import penetration has negative effect on overall inflation, consumers are enjoying low prices, thereby experiencing lower cost of living in an environment of relatively low income and economic sufferings [22]. Hence, policy-makers should take note of the trade-off that exists between a reduction in cost of living through the dampening effect of inflationary pressures against a low industrial development and loss of foreign reserves through promoting foreign direct investment and by controlling interest rates. Hence for more in-depth understanding of how these macroeconomic variables can be effective and beneficial for textile production, for boosting of economy inflation, exchange rates and external reserves are the key factors in the form of FDI. Thus, it shows that some of the other macroeconomic variables might have an impact on economic performance.

As per study of [23] stated that FDI, Trade openness, interest rate and rate of inflation were found as the essential instruments to stabilize the output returns of manufacturing export performance of Tanzania, hence the study depicts that inflation rate, FDI and Trade openness may have a major role in exports performance studied the effect of interest rate and found negative impact on return on assets of textile sector of Pakistan.

As [27] stated the long-run estimates in Ghana which indicated inflation, fiscal deficit, crowding-out effect, exchange rate volatility, deposit interest rate volatility, economic growth, money growth, and monetary policy rate increase interest rate spreads in country. However, statistically significant factors in long run were instability of exchange rate, fiscal deficit, economic growth and borrowings from commercial banks, lending interest rate instability and institutional quality reduced interest rate spread in long run, but statistically insignificant variable was coefficient of lending interest rate, whereas in short run it increases interest rate spreads, where in short run statistically significant variables were coefficient of exchange rate instability, economic growth, fiscal deficit and public sector borrowings from commercial banks. From the results in both long run and short run all the fiscal policy variables (fiscal deficit and public sector borrowings from commercial banks) were significant. It can be deducted from above discussion that monetary policy variables are dominated by the effect of variables of fiscal policy on interest rate. Higher interest rates are caused by greater risk and uncertainties in financial sector which is due to instability in fiscal policy variables. Hence shows the exchange rate might have a contribution towards the performance of an industry.

The investigation by [2] evaluated the change of imports price of host currency transmits the direct impact of exchange rate on price, consequently demand for import will increase which drives up domestic currency imports price which shows the exchange rate may have an impact on trade performance. Similarly, [42] used REER and RER as dependent variables for the countries of optimum currency area (OCA) and found exchange rate the important tool to make economy stable.

According to [39] emphasized the inflation rate, exchange rate and trade balance implications in Uganda and found trade balance could be improved by depreciation of exchange rate, trade deficit might be lessening by suitable policy implementation, inflation can be stimulated by the devaluation of exchange rate through multiple channels. Hence it can be deducted that exchange rate might be a strong role in stability of economic growth.

According to [3] examined the firm performance with interest rate, net interest and ROA and highlighted the significance of ROA with set of firm level. Similarly, [31] stated the impact of performance of textile industry of Pakistan on economic growth which elaborates the significance of the said industry. [1] stated that a company shows performance through return on assets, which shows an attainment of prior planning high commission which affect the decision to encourage or discourage the new investment. Hence ROA is more active instrument for pre planning of investment.

According to the study of [19] they concluded the association among financial performance, risk and tax and found significant association with the firm's growth and performance in form of ROA, which elaborates high tax payment led to high growth rates in textile's firm. Hence the lower cost of capital and high-performance ratios is highly co integrated towards growth rates.

\section{RESEARCH METHODOLOGY}

The population of the study is the textile sector of Pakistan whereas the sample selected is the textile weaving sector of Pakistan which comprises the data of Return on Assets (ROA) of 15 firms for 23 years of textile weaving sector. The data for FDI, TO, INF, INT and EXR, were taken as independent variables and from the official website of world development indicator.

The traditional method for time series data was used. The average of ROA of weaving sector was taken. Firstly, Unit root test will be applied through Augmented Dicky Fuller Test (ADF) for checking the stationarity of the variables of the data, based on the results of ADF, model like Vector Autoregressive Models, (VAR) following "Granger Causality" has been run through the statistical software EViews for data analysis to evaluate the influence of INF, INT, 
EXR,TO,FDI on return on assets of textile weaving sector of Pakistan to find the variations among these variables in both long and short run.

Firstly, the data of the study was comprised of time series, thus the unit root test was conducted for checking of their stationary properties. As the result might be produced as spurious if use time series data without checking their stationary properties [14], [12]. Hence it was very important to test out stochastic properties of the variables to be estimated before estimating our modified model in the equation. Thus, this task was realized by conducting unit root test. The unit root test is linked with one of its weakness that use of less than 20 numbers of observations might cause failure to get the reliable results, showing that the number of 20 observations can be made inference as stated by [15]. Therefore, the study results considered reliable as it was conducted at the data of 20 observations through (ADF) shows that all variables became stationary at first difference. The associations among all variables of the study were found insignificant at level which became significant after taking at first difference.

\section{DISCUSSION AND CONCLUSION}

TABLE 1: UNIT RoOt TEST THROUGH AUgMENTEd Dickey FulLER

\begin{tabular}{ccc}
\multicolumn{3}{c}{$(\mathrm{ADF})$} \\
\hline Variables & Probability & Difference \\
\hline ROA & 0.0029 & First \\
INF & 0.0009 & First \\
INT & 0.0001 & First \\
FDI & 0.0081 & First \\
TO & 0.0046 & First \\
EXG & 0.0348 & First \\
\hline
\end{tabular}

A. Estimated Techniques: Fully Modified Least Squares (FMOLS)

ARDL cannot be run due to insufficient number of observations. However, Modified OLS is applied for estimation of parameters. The Dependent Variable is LOG_ROA for long run adjustment the significant parameters were LOG_EXR as .01, LOG_INF as .02 and LOG_INT as 0.05 while the insignificant parameters were LOG_FDI as 0.4 and LOG_TO as:

0.9 , specified the equation as LOG_ROA = LOG_EXG+LOG_FDI+LOG_INF + LOG_INT+LOG_TO

The estimated parameters are as under see Table.3.

\begin{tabular}{ccccc}
\multicolumn{5}{c}{ TABLE 2: ESTIMATED PARAMETERS } \\
\hline Variables & Coefficient & Std. Error & t-Statistics & Prob. \\
\hline C & 3.366166 & 1.648808 & 2.041575 & 0.0620 \\
LOG_EXR & -0.809153 & 0.273211 & -2.961643 & 0.0110 \\
LOG_FDI & 0.076114 & 0.087520 & 0.869682 & 0.4002 \\
LOG_INF & -0.336484 & 0.131186 & -2.564930 & 0.0235 \\
LOG_INT & 0.172594 & 0.082772 & 2.085180 & 0.0573 \\
LOG_TO & -0.122289 & 1.019367 & -0.119966 & 0.9063 \\
\hline
\end{tabular}

The co-efficient of exchange rate is - 0.809153, which shows that Exchange rate has a negative impact over ROA of textile industry of Pakistan. That is 1 unit change in exchange rate will decrease the ROA by 81 units The probability value of exchange rate is 0.01 which shows significant impact on ROA of textile industry of Pakistan. For Foreign Direct
Investment, the coefficient is .076114 which reveals that 1 unit change in FDI will increase ROA by 7.6 units.

The Probability value is indicating insignificant relationship between the variables. Furthermore, the coefficient for Inflation rate is -0.336484 showing negative association with ROA which elaborates that 1 unit change in interest rate will decrease ROA by 33.6 unit, its Probability value of 0.02 showing significant association with ROA. Similarly, the probability value of interest rate $(0.05)$ is indicating positive and significant relationship with the dependent variable. Trade openness has an inverse relation with ROA as the coefficient becomes as -0.122289 , which describes that 1 unit change in Trade openness decreases 12.22 unit of ROA of textile weaving sector of Pakistan.

\begin{tabular}{lcll}
\multicolumn{4}{c}{ TABLE 3: CO-INTEGRATION AT LAG SELECTION } \\
\hline R-squared & 0.567209 & & Mean dependent var S.D. \\
Adjusted R- squared & 0.400751 & dependent var & 0.150567 \\
S.E. of regression & 0.116556 & Sum squared resid & 0.176608 \\
Long-run variance & 0.007027 & Akaike info criterion & 2.534248 \\
Sum squared resid & 0.055473 & Schwarz criterion & 2.387210 \\
Log likelihood & 24.54111 & Hannan-Quinn criterion. & 2.519632 \\
Durbin-Watson & 1.984171 & & \\
stat & & & \\
\hline
\end{tabular}

The coefficient of determination (R-Square) $\mathrm{R}^{2}$ is 0.567209 which depicts that $56 \%$ changes in ROA are due to independent variables included in the study.

\section{B. Co-integration Test}

Engel granger co-integration test is applied which indicated stable short run adjustment by highlighted coefficient. The max lag No. selected is 2 , based on SIC as shown below:

Equation Specification:

$$
L O G_{R O A}=L O G_{E X R} L O G_{F D I} L O G_{I N F} L O G_{I N T} L O G_{T O} C
$$

Null hypothesis: Series are not co integrated.

Automatic lag specification (Max.lag=2 based on Schwarz Info Criterion) (SIC).

TABLE 4: ENGEL GRANGER CO-INTEGRATION

\begin{tabular}{|c|c|c|c|c|}
\hline & & Value & \multicolumn{2}{|c|}{ Prob.* } \\
\hline Engel-Granger & r t-statistic & -5.325505 & \multicolumn{2}{|c|}{0.0872} \\
\hline Engel-Granger & r z-statistic & 84.09884 & \multicolumn{2}{|c|}{1.0000} \\
\hline \multicolumn{5}{|c|}{ TABLE 5: RESID (LEAST SQUARE METHOD) } \\
\hline Variables & Coefficient & Std. Error & t-Statistics & Prob. \\
\hline RESID(-1) & -2.240558 & 0.420722 & -5.325505 & 0.0001 \\
\hline $\mathrm{D}(\operatorname{RESID}(-1))$ & 1.054986 & 0.252050 & 4.185620 & 0.0009 \\
\hline $\mathrm{D}(\mathrm{RESID}(-2)$ & 0.397927 & 0.229586 & 1.733239 & 0.1050 \\
\hline R-squared & 0.820588 & \multicolumn{2}{|c|}{ Mean dependent var } & 0.006489 \\
\hline Adjusted R-squared & 0.794957 & \multicolumn{2}{|c|}{ S.D. dependent var } & 0.139013 \\
\hline S.E. of regression & 0.062947 & \multicolumn{2}{|c|}{ Akaike info criterion } & -2.534248 \\
\hline Sum squared resid & 0.055473 & \multicolumn{2}{|c|}{ Schwarz criterion } & -2.387210 \\
\hline Log likelihood & 24.54111 & \multicolumn{2}{|c|}{ Hannan-Quinn criter. } & -2.519632 \\
\hline Durbin-Watson stat & 1.984171 & & & \\
\hline
\end{tabular}

The above Table 4 and Table 5 consist of the results obtained from the tests of Engel Granger Co-integration and Residual Least Square Method. Results revealed that at Automatic Lag selection by taking 1 st $\log$, the prob. value of the residual after first difference become as 0.0009 which shows significant impact. The value of $\mathrm{R}$-Squared is 
0.820588 indicates $82 \%$ overall variations found in ROA is due to the independent variables.

In line with the hypotheses already posed and pre-selected data, the methodology of this study included the multiple regression analysis. The time-series data of annual based was taken to regress for the period of 1997-2019. There was no serial correlation and heteroscedasticity were observed indicating the reliance of the estimates; Augmented Dickey Fuller technique was carried out. The unit root test results showed that all the variables become significant after first difference, the same results were stated by [41], [37], [40] applied ordinary least square method using E-views software examined negative association of Interest Rate and Exchange Rate with FDI, Trade openness and industry performance has insignificant result which depicts the association among these variables.

This dissertation started by giving an overview about the impact of Inflation rate, Interest rate, Foreign Direct Investment Rate, Exchange rate and Trade openness on Return on Assets of Textile Industry of Pakistan This study explains that inflation, interest rate and exchange rate have significant impact while foreign direct investment and trade openness are not significantly associated with the return on assets of textile industry of Pakistan. The value of $\mathrm{R}$ square tells that variations of $56 \%$ in long run and $82 \%$ in short run were found due to independent variables on ROA of the weaving textile industry of Pakistan. However, it is obvious that besides a lot of weakness of this sector it may act as a country's economy driver due to its cheap skilled labor force, raw material productivity power and trading capabilities which would be a best motive for Government best policy for its survival. Moreover, the investigations should even make huge contribution to the literature.

\section{FUTURE RESEARCH DIRECTION}

This study limited to a linear frame work, some results may be sensitive to non-linearites. Anon-linear frame work should be included in Future research. There are other certain macroeconomic variables which are not taken in the analysis, may influence results and provide some more useful information about growth performance and economic activity association. The econometric model equation comprises fewer variables while the model may have enlarged by the adding more macro-economic variables and may exemplify the results by applying more tests. For better research studies and discovering new policies the time period for data should also be increased not considering only Pakistan but other Asian countries as well and by using panel data the efficiency of industry at larger scale may be measured which will may have significant positive impact at global level. Overall, this study is expected to be more beneficial in business literature. Keeping in view the results of the study, Government and regulatory authorities should focus at policies regarding interest rate, inflation and exchange rate as these variables have significant impact on return on assets of textile sector of Pakistan.

\section{REFERENCES}

[1] Al-Matari, E. M., Al-Swidi, A. K., \& Fadzil, F. H. B. (2014). The measurements of firm performance's dimensions. Asian Journal of Finance \& Accounting, 6(1), 24-49.

[2] Agénor, P. R., \&Montiel, P. J. (2015). Development Macroeconomics Fourth edition. Economics Books.

[3] Aysen Doyran, M. (2013). Net interest margins and firm performance in developing countries: Evidence from Argentine commercial banks. Management Research Review, 36(7), 720-742.

[4] Akalpler, E., \&Duhok, D. (2018). Does monetary policy affect economic growth: evidence from Malaysia. Journal of Economic and Administrative Sciences, 34(1), 2-20.

[5] Abbasi, 2011) Muhammad Usama Abbasi. Performance of Textile Sector, Deptt of Economics.

[6] Abbas, F., Tahir, M., Rehman, M. U., \& Perviz, A. (2012). Impact of Financial crisis on textile industry in Pakistan. Information Management and Business Review, 4(7), 409.

[7] Ahmed, Y. (2010). Textile industry of Pakistan. Horizon Securities, Lahore.

[8] Bibi, S., Ahmad, S. T., \& Rashid, H. (2014). Impact of Trade Openness, FDI, Exchange Rate and Inflation on Economic Growth: A Case Study of Pakistan. International Journal of Accounting and Financial Reporting, 4(2), 236.

[9] Bititci, U., Carrie, A., \& Mc Devitt, L. (1997). Performance measurement: A business process view. In IFIP WG 5.7 Working Conference on Modelling Techniques for Business Process Reengineering and Benchmarking.

[10] Back, K., Cao, C. H., \& Willard, G. A. (2000). Imperfect competition among informed traders. The journal of finance, 55(5), 2117-2155.

[11] Delic, M. I. L. I. C. A., \& Kragulj, D. R. A. G. A. N. A. (2007, May) Objectives of macroeconomics as the basis for clustering of countries in integrated Europe. in the 7th Balkan Conference on Operational Research "BACOR (Vol. 5).

[12] Datta, K., \& Kumar, C. K. (2011). Relationship between inflation and economic growth in Malaysia-an econometric review. In International Conference on Economics and Finance Research (Vol. 4, No. 1, pp. 415-419).

[13] Ghatak, S., \& Sánchez-Fung, J. R. (2007). Monetary economics in developing countries.Macmillan International Higher Education.

[14] Gujarati, D. N. (2004). Econométrie.De BoeckSuperieur.

[15] Gujarati, D. N., \& Porter, D. (2009). Basic Econometrics Mc Graw-Hill International Edition.

[16] Islam, M. M., Khan, A. M., \& Islam, M. M. (2013). Textile industries in Bangladesh and challenges of growth. Research Journal of Engineering Sciences.

[17] Jameel, K., Akhtar, M. N., \& Azeem, (2014) K. Causal factors of Textile sector growth: An Econometric Case Study in Pakistan. International Journal of Scientific \& Engineering Research, Volume 5, Issue 8, August-2014 (822 ISSN 2229-5518) IJSER (C) 2014 http://www.ijser.org.

[18] Kali, R., Reyes, J., McGee, J., \&Shirrell, S. (2013). Growth networks. Journal of Development Economics, 101, 216-227.

[19] Khandelwal, A., and P. Topalova (2011): "Trade Liberalization and Firm Productivity: The Case of India," Review of Economics and Statistics, 93, 995-1009.

[20] Markusen, J. R., \& Venables, A. J. (1999). Foreign direct investment as a catalyst for industrial development. European economic review, 43(2), 335-356.

[21] Mucuk, M., \& Demirsel, M. T. (2013). The effect of foreign direct investments on unemployment: Evidence from panel data for seven developing countries. Journal of Business Economics and Finance, 2(3), 53-66.

[22] Makoto, R., \& Ngendakumana, L. (2018). Chinese imports, industrial production and inflation in Zimbabwe. Journal of Chinese Economic and Foreign Trade Studies, 11(1), 2-14.

[23] Mwakanemela, K. (2014). Impact of FDI Inflows, Trade Openness and Inflation on the Manufacturing Export Performance of Tanzania: An Econometric Study. International Journal of Academic Research in Economics and Management Sciences, 3(5), 151.

[24] Neely, A., Gregory, M., \&Platts, K. (1995). Performance measurement system design: a literature review and research agenda. International journal of operations \& production management, 15(4), 80116.Research journal of international studies, 14, 21-29.

[25] Nourzad, F., \& Powell, J. J. (2003). Openness, growth, and development: Evidence from a panel of developing countries. Scientific Journal of Administrative Development.

[26] Olayiwola, W. K., \&Rutaihwa, J. L. (2010). Trade liberalization and employment performance of textile and clothing industry in Tanzania. International Business Research, 3(3), 47. 
[27] Obeng, S. K., \&Sakyi, D. (2017). Macroeconomic determinants of interest rate spreads in Ghana. African Journal of Economic and Management Studies, 8(1), 76-88.

[28] Pepinsky, T. B. (2009). Economic crises and the breakdown of authoritarian regimes: Indonesia and Malaysia in comparative perspective. Cambridge University Press.

[29] Rostami, S., \&Mosavi, A. (2016). A study on effect of economic openness and inflation on profitability in the banks listed in Tehran stock exchange. International Journal of Humanities and Cultural Studies (IJHCS) ISSN 2356-5926, 280-291.

[30] Rodriguez-Clare, A. (1996). Multinationals, linkages, and economic development. The American Economic Review, 852-873.

[31] Shah, S. A. S., syed, a. A. S. G., \&shaikh, f. M. (2014). Impact of textile industry on Pakistan economy. Romanian statistical review supplement, 62(3), 43-59.

[32] Silajdzic, S., \&Mehic, E. (2017). The Impact of Environmental Taxes on Competitive Performance of Pollution-Intensive Industries Among Transition Economies:

[33] Shah, H. \&Sajid, A. (2013). Effect of Dumping and Subsidies as Trade Barrier on Productivity of Textile Industry of Pakistan. Journal of Social Sciences \& Humanities (1994-7046), 21(1).

[34] Shah, S. M. H., \& sajid, a. (2013). The impact of tariffs on productivity of Pakistan's textile industry. Management (ijfm), 2(3), 1-10.

[35] Tahir, M., \& Khan, I. (2014). Trade openness and economic growth in the Asian region. Journal of Chinese Economic and Foreign Trade Studies, 7(3), 136-152.

[36] World Bank. (2011). World development report 2011: Conflict, security, and development. World Bank.

[37] Yang, J. Y., Lu, J., \& Jiang, R. (2017). Too slow or too fast? Speed of FDI expansions, industry globalization, and firm performance. Long Range Planning, 50(1), 74-92.

[38] Yanikkaya, H. (2003). Trade openness and economic growth: a crosscountry empirical investigation. Journal of Development economics, 72(1), 57-89.

[39] Yiheyis, Z., \& Musila, J. (2018). The dynamics of inflation, exchange rates and the trade balance in a small economy: The case of Uganda. International Journal of Development Issues.

[40] Zhongqiang, B. (2014). Study on the impact of inflation on the stock market in China. International Journal of Business and Social Science, 5(7), 261-271.

[41] Zaristan Mangal (2017) Effect of Macroeconomic Variables on Foreign Direct Investment in Pakistan.

[42] Zerihun, M. F., Breitenbach, M. C., \&Kemegue, F. (2016). Exploring exchange rate based policy coordination in SADC. Studies in Economics and Finance, 33(4), 576-594. 